\title{
Tomato grafting onto Solanaceae genotypes to control bacterial wilt (Ralstonia solanacearum Smith 1896) ${ }^{1}$
}

\author{
Lívia Tálita da Silva Carvalho², Danilo Mesquita Melo², \\ Pablo Forlan Vargas ${ }^{4}$, Helane Cristina Aguiar Santos ${ }^{5}$, Jessica Vasconcelos Ferreira ${ }^{3}$
}

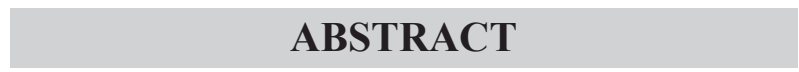

The tomato cultivation in the Amazon is not feasible mainly due to the natural infestation of Ralstonia solanacearum in the soil. Preventive control through grafting has been one of the main alternatives to manage this problem. This study aimed to evaluate the compatibility of Solanaceae genotypes as rootstocks for 'Santa Clara' tomato, aiming to control the bacterial wilt. Five rootstocks were evaluated: cubiu; red jurubeba; jurubebão; commercial hybrid tomato rootstock Guardião; and 'Santa Clara' tomato (self-grafting). In the seedling phase, characteristics of rootstock survival rate and compatibility were evaluated; while, in the field, that happened for survival rate, compatibility and fruit yield. In the seedling phase, Guardião and red jurubeba showed the best performances. In the field, red jurubeba presented a low compatibility, although it obtained the best productive performance among the wild rootstocks. Guardião obtained the best compatibility and yield among the studied rootstocks. Grafting is a viable technique for tomato production under soilborne disease conditions.

KEYWORDS: Solanum stramoniifolium, Solanum crinitum, Solanum sessiliflorum.

\section{INTRODUCTION}

Tomato (Solanum lycopersicum L.) belongs to the Solanaceae family and comes from Andean regions inhabited by the Incas in Peru, Bolivia and Ecuador (Filgueira 2007). It is cropped in practically all geographical regions of the world, under different cultivation and management systems. It is one of the

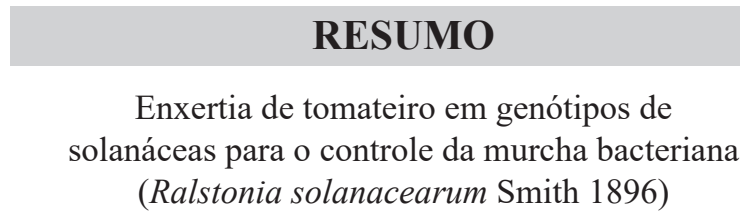

$\mathrm{Na}$ Amazônia, o cultivo de tomateiro é inviabilizado, principalmente, pela infestação natural de Ralstonia solanacearum no solo. O controle preventivo por meio de enxertia tem sido uma das principais formas de contornar o problema. Objetivou-se avaliar a compatibilidade de genótipos de solanáceas como porta-enxertos para o tomateiro 'Santa Clara', visando ao controle da murcha bacteriana. Foram avaliados cinco porta-enxertos: cubiu; jurubeba vermelha; jurubebão; porta-enxerto comercial de tomateiro híbrido Guardião; e tomateiro 'Santa Clara' (autoenxertia). Em fase de muda, foram avaliadas características de pegamento da enxertia e compatibilidade; e, em campo, a taxa de sobrevivência, compatibilidade e produtividade das plantas. Na fase de muda, Guardião e jurubeba vermelha apresentaram os melhores desempenhos. Em campo, a jurubeba vermelha demonstrou baixa compatibilidade, embora tenha obtido o melhor desempenho produtivo entre os porta-enxertos silvestres. Guardião obteve a melhor compatibilidade e produtividade dentre os porta-enxertos estudados. A enxertia é uma técnica viável para a produção de tomateiro em condições de patógenos no solo.

PALAVRAS-CHAVE: Solanum stramoniifolium, Solanum crinitum, Solanum sessiliflorum.

most consumed vegetables worldwide and one of the main vegetables produced in Brazil, reaching the fresh or processed consumer market (Conab 2019).

Most of the Brazilian tomato production is concentrated in the states of Goiás, São Paulo and Minas Gerais. The northern region, in 2018, was responsible for the production of over 11.9 thousand tons of tomato, with 6.2 thousand tons of this

\footnotetext{
${ }^{1}$ Received: May 14, 2020. Accepted: July 09, 2020. Published: Aug. 10, 2020. DOI: 10.1590/1983-40632020v5063476.

${ }^{2}$ Universidade Estadual Paulista, Departamento de Produção Vegetal, Jaboticabal, SP, Brasil. E-mail/ORCID: livia.carvalho@unesp.br/0000-0002-0312-7897.

${ }^{3}$ Universidade Federal Rural da Amazônia, Campus Capanema, Capanema, PA, Brasil. E-mail/ORCID: danilo.melo@ufra.edu.br/0000-0003-4527-0269, jessica.vf.07@gmail.com/0000-0001-6808-697X.

${ }^{4}$ Universidade Estadual Paulista, Campus Experimental de Registro, Registro, SP, Brasil. E-mail/ORCID: pablo.vargas@unesp.br/0000-0002-5718-6403.

${ }^{5}$ Universidade Federal Rural da Amazônia, Campus Belém, Belém, PA, Brasil. E-mail/ORCID: aguiar.halane@gmail.com/0000-0002-4818-3569.
} 
production referring to the state of Pará; an incipient value, when compared to the national production (Agrianual 2019).

The combination of high temperature and relative humidity in the Brazilian northern region creates an environment favorable to soil-borne diseases, complicating the production in the Amazon. Among these, the bacterial wilt, caused by Ralstonia solanacearum (Smith 1896), is one of the main diseases of Solanaceae in tropical climates (Lopes et al. 2015).

The control of bacterial wilt after its establishment in the field is difficult, due to the large number of hosts and the inefficiency of chemical control. For this reason, integrated management should be adopted, based on the observation of several preventive and complementary control measures (Lopes 2009).

In this scenario, grafting emerges as an alternative for disease control, wherein the resistant rootstock remains healthy, assuming the role of absorbing water and nutrients from the soil, whilst isolating the susceptible cultivar from the pathogen present in the soil (Peil 2003), requiring compatibility between the rootstock and the scion (Fernandes 2016).

Compatibility is the ability of a plant grafted onto another to successfully achieve union and development as a single plant; and incompatibility is the total or partial lack of survival of grafted seedlings (Miguel 1997). The greater the genetic or botanical affinity between the plants to be grafted, the greater is the compatibility and the probability of success in grafting (Peil 2003).

The use of commercial rootstocks for tomato has become popular because, in addition to protecting the plant against diseases, it reduces the problem of incompatibility associated with the use of different species/genera (Lopes et al. 2015).

Thus, the use of tomato hybrids as rootstock has the advantage of facilitating the grafted seedlings production, with a high rate of success. However, there is the disadvantage that the resistance level of the rootstock is not complete (Lopes 2009). In contrast, grafting tomato onto wild Solanaceae species guarantees a better level of protection for the plant, but also a possible compatibility problem (Lopes 2009).

For this reason, the use of native Solanaceae, which are adapted to local conditions (high temperatures and relative humidity) and develop naturally in these soils, must be based on careful tests that prove both compatibility and resistance to soil-borne diseases.

In this context, this study aimed to evaluate the compatibility of Solanaceae genotypes as rootstock for 'Santa Clara' tomato, aiming to control the bacterial wilt in soil naturally infested with $R$. solanacearum.

\section{MATERIAL AND METHODS}

The study was carried out at the Universidade Federal Rural da Amazônia, in Igarapé-Açu, Pará state, Brazil, from July to December 2018. The climate of the region is Am $_{i}$, according to the Köppen's classification (Alvares et al. 2013). Temperature and relative humidity data for the growing period are shown in Figure 1.

The experiment was divided into two evaluation phases: the first on nursery seedlings and the second on plants under permanent cultivation, in a greenhouse. In the seedling phase, a completely randomized design was used, with five treatments (rootstocks), four replications and five plants grafted per replication. In the permanent cultivation, a randomized block design was used, with five treatments (rootstocks), four replications and four grafted plants per replication.

Five rootstocks (treatments) were evaluated: cubiu (Solanum sessiliflorum Dunal); red jurubeba (Solanum stramoniifolium Jacq.); jurubebão (Solanum crinitum Lam.); commercial hybrid tomato rootstock Guardião (Takii Seed ${ }^{\mathrm{TM}}$ ); and 'Santa Clara' tomato $\left(\right.$ Feltrin $\left.^{\mathrm{TM}}\right)$ (self-grafting).

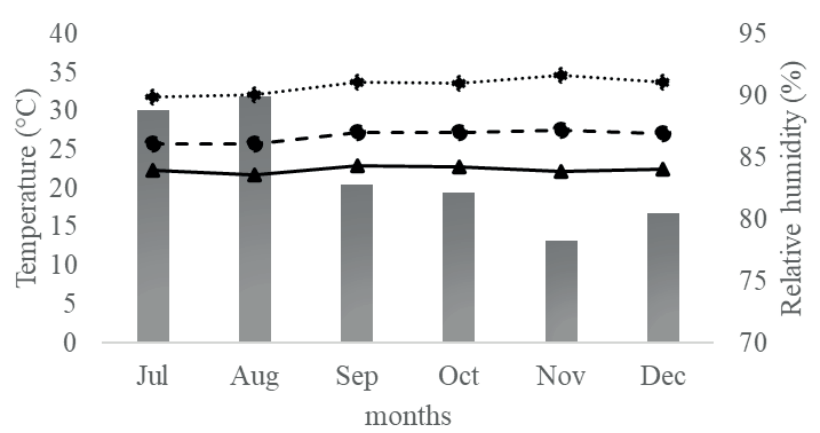

RU (\%) … MaxTemp —-MinTemp - • AveTemp

Figure 1. Temperature and relative humidity data collected at an automatic meteorological station in Igarapé-Açu (Pará state, Brazil), during the experimental period (July to December 2018). 
The 'Santa Clara' tomato was used as scion because it is the cultivar most used by tomato growers in the region.

The sowing of rootstocks and self-grafts was carried out in a greenhouse (nursery), in expanded polystyrene trays with 200 cells containing Tropstrato HT Hortaliças ${ }^{\mathrm{TM}}$ commercial substrate. Two seeds were sown per cell, with subsequent thinning at five days after the seedling emergence. The rootstocks cubiu and jurubebas were sown at 30 days before the scion, due to the difference in emergence and growth.

The plants were grafted at 24 days after the emergence of the scions, presenting three to four true leaves and diameter similar to that of the rootstocks, approximately $3.00 \mathrm{~mm}$ below the cotyledon leaves, where the cut for the grafting was performed. The seedlings were cleft grafted.

To perform the grafting, carbon steel blades and grafting clips were used. The grafted seedlings were placed in a humid chamber until healing. Five days after grafting, the trays containing the grafted plants were placed in a suspended structure, in the seedling nursery, until the evaluations.

The seedlings were evaluated for survival rate at 15 days after grafting - obtained by counting the number of healed grafted plants, expressed as percentage (\%); seedling height - determined from the base of the seedling stem to the insertion of the last leaf; number of leaves; scion and rootstock diameter - measured at $1.5 \mathrm{~cm}$ above and below the grafting region, respectively, using a digital caliper $(\mathrm{mm})$; stem and leaf fresh mass - determined by weighing the fresh stem and leaves on a precision scale $(0.001 \mathrm{~g})$; and stem and leaf dry mass determined by storing the stem and leaves in an oven with air circulation at $65^{\circ} \mathrm{C}$, for 72 hours, followed by weighing the dry mass on a precision scale $(0.001 \mathrm{~g})$.

Before the installation of the field experiment, the glass test was performed according to Becker et al. (2016), in tomato plants of the same cultivar planted in the same area of the experiment. The presence of $R$. solanacearum was identified in the soil due to the exudation of the characteristic bacterial pus.

The soil chemical analysis was carried out for liming, planting and cover fertilization, using the recommendation described in Cravo et al. (2007).

The plants were transplanted to the soil at 24 days after grafting, in an arch-type greenhouse, $30 \mathrm{~m}$ long and $16 \mathrm{~m}$ wide, $3.5 \mathrm{~m}$ high ceiling, side protection screen with $50 \%$ shading and ceiling covered with 150 -micron thick low-density polyethylene film. The spacing used was $0.5 \mathrm{~m}$ between plants and $1.0 \mathrm{~m}$ between lines, with four plants per plot.

The two-stemmed plants were tutored using a vertical stake. Apical pruning was performed when the plants reached $250 \mathrm{~cm}$. The irrigation system adopted was drip tape.

The plant-health control was performed preventively with the use of a copper oxychloridebased fungicide, weekly and immediately after pruning the plants.

At 30 and 62 days after transplanting, the plant survival rate was determined. At 62 days after transplanting, the compatibility index was determined through the ratio between the rootstock and scion diameter at $\pm 1 \mathrm{~cm}$ from the grafting region (Simões et al. 2014).

Six harvests were carried out, being evaluated the number of fruits per plant, fresh and dry fruit mass, and yield. At the fifth harvest, the soluble solids content (expressed as ${ }^{\circ}$ Brix and measured with an analog refractometer; AOAC 2000), cross-sectional and longitudinal fruit diameter were also evaluated. For these evaluations, the four plants of the plot were considered, and five fruits per plant were assessed. The evaluated fruits were classified according to the minimum quality standard established by the Companhia de Entrepostos e Armazéns Gerais de São Paulo (CEAGESP 2019).

The data were submitted to the $\mathrm{F}$ test and the averages compared by the Tukey test at $5 \%$ of probability. The variables plant survival rate after grafting and transplanting were transformed to $\operatorname{arcsine} \sqrt{ }(\mathrm{x} / 100)$ (Nishijima et al. 1992), using the statistical software AgroEstat (Barbosa \& Maldonado 2011).

\section{RESULTS AND DISCUSSION}

All treatments, except for jurubebão $(83.33 \%)$, presented a percentage of $100 \%$ of survival success (Table 1). The self-grafted treatment, as well as most of the tested wild genotypes, demonstrated that the conditions in which the grafting was performed favored healing, without interfering in the process of structure union. This result is also the first indication that jurubebão presents less morphological/ physiological affinity with the scion, when compared to self-grafting. No statistical difference was detected 
Table 1. Survival percentage in 'Santa Clara' grafted tomato seedlings, at 15 days after grafting.

\begin{tabular}{lc}
\hline \multicolumn{1}{c}{ Treatment } & Survival percentage \\
\hline Cubiu & $100 \mathrm{a}$ \\
Red jurubeba & $100 \mathrm{a}$ \\
Jurubebão & $83 \mathrm{a}$ \\
Guardião & $100 \mathrm{a}$ \\
Self-grafting & $100 \mathrm{a}$ \\
\hline F test & $1.9^{\text {ns }}$ \\
\hline CV $(\%)$ & 6.37 \\
\hline
\end{tabular}

between the treatments; however, the death of the plants of this treatment indicates the discontinuity in the vascular bundles between the species, a sign of incompatibility, in the first days after grafting.

Fernandes (2016) obtained a $100 \%$ survival rate for all treatments, including cubiu, jurubeba (Solanum viarum Dunal) and 'Yoshimatsu' tomato, using 'Santa Cruz Kada Gigante' (Feltrin ${ }^{\mathrm{TM}}$ ) tomato as scion.

Similar results were observed by Cantu (2009), who worked with the rootstocks Guardião ${ }^{\mathrm{TM}}$, Helper-MTM, Anchor-T ${ }^{\mathrm{TM}}$, Dr. K ${ }^{\mathrm{TM}}$, Kagemuscha ${ }^{\mathrm{TM}}$, Block $^{\mathrm{TM}}$, Magnet ${ }^{\mathrm{TM}}$ and He-Man ${ }^{\mathrm{TM}}$, with the commercial hybrid Paron ${ }^{\mathrm{TM}}$ as scion, obtaining a survival rate of $100 \%$ for all rootstocks. However, in the aforementioned study, all rootstocks used are commercial genotypes, differing from the present study, which aimed, above all, to use genotypes adapted to the local edaphoclimatic conditions of the study region.

As for the characteristics related to the seedlings development after grafting, the height of the seedlings differed among the treatments, demonstrating that the red jurubeba, Guardião and self-grafting were the best treatments (Table 2). At the initial stage of the newly grafted seedling, the plant undergoes some stresses that result in growth delay, due to the rupture of the conducting vessels. After this time of development stoppage, the plant re-establishes itself, giving conditions for growth after the cell divisions of the vessels, if there is compatibility between the rootstock and scion (Simões et al. 2014). Santos \& Goto (2004) reported that, at the initial stage, after grafting, it is important to note that the early development of a grafted plant is a good suggestion of compatibility.

The treatments cubiu, red jurubeba and selfgrafting presented the best values for the variable number of leaves. However, cubiu and self-grafting did not differ from the treatments jurubebão and Guardião, which presented the lowest averages for number of leaves. This difference, therefore, may be related to the plant adaptation after grafting.

There was no significant difference between the treatments for scion diameter. For rootstock diameter, cubiu presented a larger diameter (Table 2). In general, the rootstocks showed larger diameters than the scion for all treatments, possibly due to the morphological difference between the studied species, which present larger diameters than the tomato, mainly jurubebão and cubiu, in which the diameter difference is greater (Table 2). Assessing the stem diameter of grafted plants is very important, especially to detect the level of compatibility between species.

The difference between the scion and rootstock diameters may be considered an incompatibility parameter, considering that there is an accumulation of cells near the grafting region. However, with the

Table 2. Seedlings height (SH), number of leaves (NL), scion diameter (SD), rootstock diameter (RD), fresh stem mass (FSM), fresh leaf mass (FLM), dry stem mass (DSM) and dry leaf mass (DLM) of tomato seedlings grafted onto Solanaceae rootstocks, at 15 days after grafting.

\begin{tabular}{|c|c|c|c|c|c|c|c|c|}
\hline Treatment & $\begin{array}{l}\mathrm{SH} \\
\mathrm{cm}\end{array}$ & NL & SD & $\mathrm{RD}$ & FLM & DLM & FSM & DSM \\
\hline Cubiu & $27.00 \mathrm{~b}$ & $4.50 \mathrm{ab}$ & $4.46 \mathrm{a}$ & $7.54 \mathrm{a}$ & $2.88 \mathrm{ab}$ & $0.34 \mathrm{ab}$ & $4.76 \mathrm{bc}$ & $0.40 \mathrm{bc}$ \\
\hline Red jurubeba & $45.25 \mathrm{a}$ & $5.75 \mathrm{a}$ & $4.52 \mathrm{a}$ & $4.45 \mathrm{~b}$ & $3.53 \mathrm{a}$ & $0.40 \mathrm{a}$ & $6.64 \mathrm{ab}$ & $0.92 \mathrm{a}$ \\
\hline Jurubebão & $18.75 \mathrm{~b}$ & $4.00 \mathrm{~b}$ & $3.77 \mathrm{a}$ & $5.30 \mathrm{~b}$ & $1.41 \mathrm{~b}$ & $0.13 \mathrm{~b}$ & $1.98 \mathrm{~d}$ & $0.20 \mathrm{c}$ \\
\hline Guardião & $52.00 \mathrm{a}$ & $3.75 \mathrm{~b}$ & $3.62 \mathrm{a}$ & $4.42 \mathrm{~b}$ & $2.22 \mathrm{ab}$ & $0.21 \mathrm{ab}$ & $7.72 \mathrm{a}$ & $0.67 \mathrm{ab}$ \\
\hline Self-grafting & $52.50 \mathrm{a}$ & $4.25 \mathrm{ab}$ & $4.06 \mathrm{a}$ & $4.31 \mathrm{~b}$ & $3.48 \mathrm{a}$ & $0.33 \mathrm{ab}$ & $4.49 \mathrm{c}$ & $0.41 \mathrm{bc}$ \\
\hline F test & $34.51 * *$ & $3.93 *$ & $1.97^{\mathrm{n}} \mathrm{S}$ & $15.13 * *$ & $6.85 * *$ & $3.95 *$ & $21.94 * *$ & $18.37 * *$ \\
\hline $\mathrm{CV}(\%)$ & 13.37 & 17.64 & 13.93 & 13.47 & 25.34 & 37.51 & 18.37 & 24.84 \\
\hline
\end{tabular}

Means followed by the same letter in the same column do not differ by the Tukey test at $5 \%$ of probability. ** Significant by the $\mathrm{F}$ test at $1 \%$ of probability; * significant by the $\mathrm{F}$ test at $5 \%$ of probability; ${ }^{\mathrm{ns}}$ not significant at $5 \%$ of probability; $\mathrm{CV}$ : coefficient of variation. 
analysis of the other characteristics, in the seedling phase, it is still not possible to affirm the lack of compatibility among the other treatments tested, except for jurubebão, which only equaled the other treatments for scion diameter, presenting, for the other variables, the worst results.

At 15 days after grafting, significant differences among the treatments were verified for fresh stem and leaf mass (Table 2).

For fresh leaf mass, jurubebão differed from red jurubeba and self-grafting, which presented the best values. For dry leaf mass, red jurubeba showed the best result, only differing from jurubebão. The Guardião treatment, which presented the best value for fresh stem mass, differed from cubiu, jurubebão and self-grafting, with no difference in relation to red jurubeba. For dry stem mass, red jurubeba showed the best result, not differing from Guardião, which did not differ from the cubiu and self-grafting treatments.

There was an average value of $97.50 \%$ for plant survival rate at 30 days after transplanting, with death only for the self-grafting treatment, which did not differ statistically from the other treatments though. At 62 days after transplanting, the selfgrafting treatment differed from the others, with a survival rate of $6.25 \%$ (Table 3 ).

These results confirm that 'Santa Clara' is not resistant to $R$. Solanacearum, which was naturally present in the soil where the cultivation was carried out. Therefore, non-grafted 'Santa Clara' is not recommended for the region, considering that the death of the plants was due to the cultivar susceptibility, as in the seedling phase the self-grafted plants showed a good compatibility and high survival rate.

As for the compatibility index evaluated at 62 days after transplanting, the cubiu, jurubebão and Guardião treatments showed ratios closest to 1 , not differing from each other (Table 3).

Martins (2012) argues that the best compatibility indexes are those with values close to 1 . The red jurubeba treatment, although resulting in a compatibility index with a value more distant from 1, differing from the other treatments, cannot yet be considered incompatible with 'Santa Clara', because other characteristics, such as productive performance and plant survival, need to be observed to complete the incompatibility diagnosis.

Simões et al. (2014) also reported a compatibility index quite distant from 1 for red
Table 3. Plant survival rate (PS; \%), at 30 and 62 days after transplanting (DAT), and compatibility index (CI), at 62 DAT, of tomato grafted onto Solanaceae.

\begin{tabular}{lccc}
\hline \multicolumn{1}{c}{ Treatment } & PS - 30 DAT & PS - 62 DAT & CI \\
\hline Cubiu & $100.00 \mathrm{a}$ & $87.50 \mathrm{a}$ & $0.97 \mathrm{a}$ \\
Red jurubeba & $100.00 \mathrm{a}$ & $100.00 \mathrm{a}$ & $0.71 \mathrm{~b}$ \\
Jurubebão & $100.00 \mathrm{a}$ & $93.75 \mathrm{a}$ & $1.00 \mathrm{a}$ \\
Guardião & $100.00 \mathrm{a}$ & $100.00 \mathrm{a}$ & $0.99 \mathrm{a}$ \\
Self-grafting & $87.50 \mathrm{a}$ & $6.25 \mathrm{~b}$ & - \\
F test & $1.00^{\text {ns }}$ & $21.59^{* *}$ & $12.13^{* *}$ \\
\hline CV $(\%)$ & 11.46 & 21.68 & 8.50 \\
\hline
\end{tabular}

Means followed by the same letter in the same column do not differ by the Tukey test at $5 \%$ of probability. ${ }^{* *}$ Significant by the $\mathrm{F}$ test at $1 \%$ of probability; ${ }^{\text {ns }}$ not significant at $5 \%$ of probability.

jurubeba, but did not observe incompatibility with the tested tomato cultivar. Therefore, compatibility should not be measured with just one characteristic, but with all of them.

The treatments varied for number of fruits per plant and yield (Table 4). Regarding the number of fruits per plant, Guardião showed the best result, producing 23 fruits per plant. Mendonça et al. (2017) observed a lower result employing Guardião as a rootstock for 'Ellen' (Feltrin $\left.{ }^{\mathrm{TM}}\right)$ tomato, obtaining 7.5 fruits per plant in six harvests.

There was $0.624 \mathrm{~kg}$ plant $^{-1}$ in yield for Guardião as a rootstock, being the best treatment. However, the yield was lower than the national average, what may be explained by the high local temperatures.

Among the climatic factors, temperature is the one that most affects tomato. According to Filgueira (2007), the optimum temperature for tomato production varies between $21{ }^{\circ} \mathrm{C}$ and $28{ }^{\circ} \mathrm{C}$ during the day and $15{ }^{\circ} \mathrm{C}$ and $20{ }^{\circ} \mathrm{C}$ during the night, and higher day and night temperatures affect the fruiting and fruit fixation. The fall of tomato flowers grown in an environment with daytime temperatures above $32{ }^{\circ} \mathrm{C}$ is due to the impracticability of the pollen grain and the non-fertilization of eggs (Gusmão et al. 2006). Furthermore, the air temperature in a protected environment is always higher than in the open (Beltrão et al. 2002, Silva et al. 2002). Thus, the temperatures observed during the study period (Figure 1) are outside the appropriate range for tomato growth and development, reflecting on the final fruit production.

For fresh and dry fruit mass, there was no statistical difference among the treatments. Average 
Table 4. Number of fruits per plant (NFP), fresh fruit mass (FFM), dry fruit mass (DFM), transversal fruit diameter (TD), longitudinal fruit diameter (LD), soluble solids content (SS) and yield of tomato plants grafted onto Solanaceae.

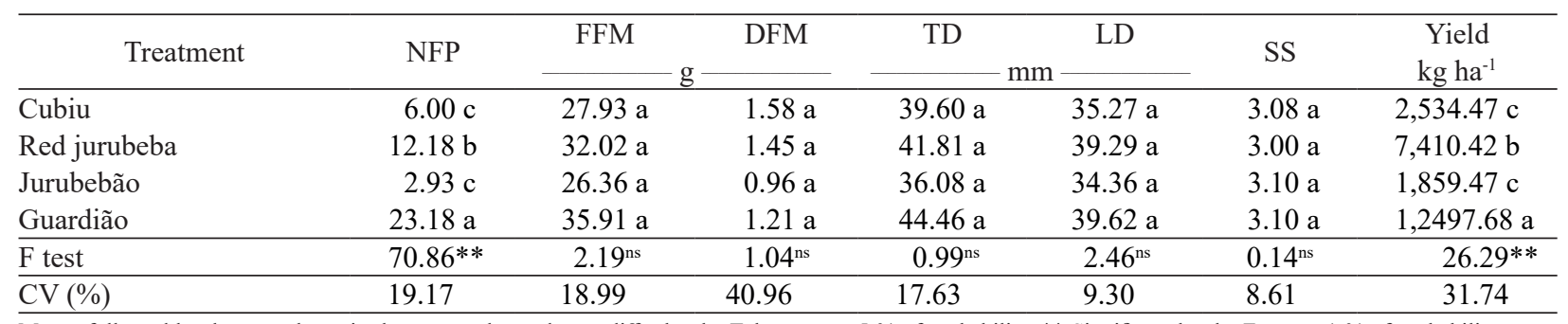

Means followed by the same letter in the same column do not differ by the Tukey test at $5 \%$ of probability. ${ }^{* *}$ Significant by the $\mathrm{F}$ test at $1 \%$ of probability; ${ }^{\text {ns }}$ not significant at $5 \%$ of probability.

values of $35.91 \mathrm{~g}$ and $1.21 \mathrm{~g}$ were observed for fresh and dry fruit mass, respectively (Table 4).

Different values for fresh fruit mass were found by Cardoso et al. (2006), evaluating the quality of tomato fruits with and without grafting of 'Santa Clara' and 'Santa Cruz Kada' cultivars, and the hybrid 'Débora Plus', reporting values higher than those obtained in the present study for all the evaluated treatments.

As for the quality characteristics, there was no effect of treatments. Mean values of $40.48 \mathrm{~mm}$ and $37.13 \mathrm{~mm}$ were found for transversal and longitudinal diameter, respectively (Table 4). According to Cardoso et al. (2006), grafting does not alter fruit physical characteristics. These same authors found higher values than those in this study when they physically characterized tomato fruits from grafted plants, in comparison with non-grafted plants, not observing any difference between treatments. Gomes et al. (2017), working with rootstocks for four-stemmed tomato, also detected no difference between treatments.

The soluble solids content is responsible for the fruit flavor and influences the consumers choice. In this study, the mean value for soluble solids was $3.07^{\circ}$ Brix, with no difference among the treatments (Table 4). These values are lower than those observed by Loos et al. (2009), testing 'Santa Clara' grafted onto 'Hawaii 7996' rootstock, wherein they obtained a soluble solids content of $4.30^{\circ}$ Brix.

\section{CONCLUSIONS}

1. Grafting is a viable technique for tomato production under soil-borne disease conditions;

2. The commercial rootstock Guardião is recommended for the study region, since it showed a high compatibility index and $100 \%$ of plant survival, as well as a higher yield;

3. Red jurubeba showed lower indications of compatibility; however, it provided the best productive performance to tomato among the wild rootstocks, being able to be tested with other cultivars for compatibility.

\section{REFERENCES}

AGRIANUAL: anuário da agricultura brasileira. 24. ed. São Paulo: FNP Consultoria e Comércio, 2019.

ALVARES, C. A.; STAPE, J. L.; SENTELHAS, P. C.; GONÇALVES, J. L. M.; SPAROVEK, G. Köppen's climate classification map for Brazil. Meteorologische Zeitschrift, v. 22, n. 6, p. 711-728, 2013.

ASSOCIATION OF OFFICIAL ANALYTICAL CHEMISTS (AOAC). Official methods of analysis of AOAC International. 17. ed. Gaythersburg: AOAC, 2000.

BARBOSA, J. C.; MALDONADO JUNIOR, W. Experimentação agronômica \& AgroEstat: sistema para análises estatísticas de ensaios agronômicos. Versão 1.1.0.712. Jaboticabal: FCAV/Unesp, 2011.

BECKER, W. F.; WAMSER, A. F.; FELTRIM, A. L.; SUZUKI, A.; SANTOS, J. P.; VALMORBIDA, J.; HAHN, L.; MARCUZZO, L. L.; MUELLER, S. Sistema de produção integrada para o tomate tutorado em Santa Catarina. Florianópolis: Epagri, 2016.

BELTRÃO, N. E. de M.; FIDELES FILHO, J.; FIGUEIREDO, I. C. de M. Uso adequado de casa-devegetação e de telados na experimentação agrícola. Revista Brasileira de Engenharia Agrícola e Ambiental, v. 6, n. 3, p. 547-552, 2002.

CANTU, R. R.; WILCKEN, S. R. S.; ROSA, J. M. O.; GOTO, R. Reação de porta-enxertos comerciais de tomateiro a Meloidogyne mayaguensis. Summa Phytopathologica, v. 35, n. 3, p. 216-218, 2009. 
CARDOSO, S. C.; SOARES, A. C. F.; BRITO, A. S.; CARVALHO, L. A.; PEIXOTO, C. C.; PEREIRA, M. E. C.; GOES, E. Qualidade de frutos de tomateiro com e sem enxertia. Bragantia, v. 65, n. 2, p. 269-274, 2006.

COMPANHIA DE ENTREPOSTOS E ARMAZÉNS GERAIS DE SÃO PAULO (CEAGESP). Tomate: padrão mínimo de qualidade. Disponível em: http://www.ceagesp. gov.br/entrepostos/servicos/hortiescolha/tomate/. Acesso em: 23 jan. 2019.

COMPANHIA NACIONAL DE ABASTECIMENTO (Conab). Compêndio de estudos Conab. Brasília, DF: Conab, 2019.

CRAVO, M. da S.; VIÉGAS, I. de J. M.; BRASIL, E. C. Recomendações de adubação e calagem para o estado do Pará. Belém: Embrapa Amazônia Oriental, 2007.

FERNANDES, B. dos S. Uso da enxertia para o controle da murcha bacteriana (Ralstonia solanacearum Smith (1896) (Yabuuchi) et al. 1996) no tomateiro. 2016. Dissertação (Mestrado em Agronomia Tropical) Universidade Federal do Amazonas, Manaus, 2016.

FILGUEIRA, F. A. R. Novo manual de olericultura: agrotecnologia moderna na produção e comercialização de hortaliças. 3. ed. Viçosa: Ed. UFV, 2007.

GOMES, R. F.; CASTOUDI, R.; MELO, D. M.; BRAZ, L. T.; SANTOS, D. M. M. S. Porta-enxertos para tomateiro conduzido com quatro hastes. Revista Ceres, v. 64, n. 2, p. 186-191, 2017.

GUSMÃO, M. T. A.; GUSMÃO, S. A. L.; ARAÚJO, J. A. C. Produtividade de tomate tipo cereja cultivado em ambiente protegido em diferentes substratos. Horticultura Brasileira, v. 24, n. 4, p. 431-436, 2006.

LOOS, R. A.; CALIMAN, F. R. B.; SILVA, D. J. H. Enxertia, produção e qualidade de tomateiros cultivados em ambiente protegido. Ciência Rural, v. 39, n. 1, p. 232-235, 2009.

LOPES, C. A. Murcha bacteriana ou murchadeira: uma inimiga do tomateiro em climas quentes. Brasília, DF: Embrapa Hortaliças, 2009.
LOPES, C. A.; BOITEUX L. S.; ESCHEMBACK, V. Eficácia relativa de porta-enxertos comerciais de tomateiro no controle da murcha-bacteriana. Horticultura Brasileira, v. 33, n. 1, p. 125-130, 2015.

MARTINS, W. M. de O. Compatibilidade e desempenho agronômico de pimentão enxertado em sistema orgânico nas condições climáticas de Rio Branco - Acre. 2012. Dissertação (Mestrado em Agronomia) - Universidade Federal do Acre, Rio Branco, 2012.

MENDONÇA, J. L.; LOPES, C. A.; MOITA, A. W. Compatibilidade de enxertia de híbridos interespecíficos de Solanum com tomateiro visando controle de patógenos de solo. Savannah Journal of Research and Development, v. 1, n. 1, p. 34-38, 2017.

MIGUEL, A. G. Injerto em hortalizas Espanha: generalitat valenciana. Valencia: Conselleria de Agricultura, Pesca y Alimentación, 1997.

NISHIJIMA, K. A.; MIURA, C. K.; ARMSTRONG, J. W.; BROWN, S. A.; HU, B. K. S. Effect of forced, hot-air treatment of papaya fruit on fruit quality and incidence of postharvest diseases. Plant Disease, v. 76, n. 7, p. 723727, 1992.

PEIL, R. M. A enxertia na produção de hortaliças. Ciência Rural, v. 33, n. 6, p. 1169-1177, 2003.

SANTOS, H. S.; GOTO, R. Enxertia em plantas de pimentão no controle da murcha de fitóftora em ambiente protegido. Horticultura Brasileira, v. 22, n. 1, p. 45-49, 2004.

SILVA, M. A. A.; ESCOBEDO, J. F.; GALVANI, M. Influência da cultura do pimentão (Capsicum annuum L.) nos elementos ambientais em ambiente protegido. Irriga, v. 7, n. 3, p. 230-240, 2002.

SIMÕES, A. C.; ALVES, G. E. B.; FERREIRA, R. L. F.; ARAÚJO NETO, S. E.; ROCHA, J. F. Compatibilidade de tomateiro sob diferentes porta-enxertos e métodos de enxertia em sistema orgânico. Enciclopédia Biosfera, v. 10, n. 18, p. 961-972, 2014. 